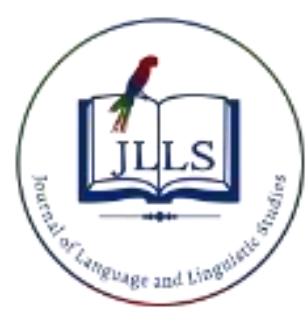

Available online at www.jlls.org

JOURNAL OF LANGUAGE AND LINGUISTIC STUDIES

ISSN: $1305-578 \mathrm{X}$

Journal of Language and Linguistic Studies, 16(1), 366-389; 2020

\title{
Development of a training module to improve initial ELT proficiency among student-teachers in multi-ethnic community schools
}

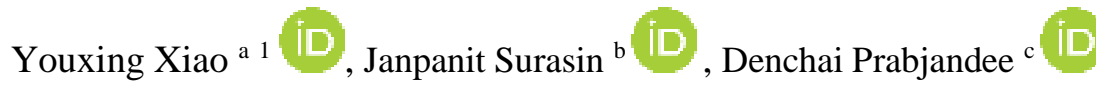 \\ a Dali University, Dali, Yunnan, 671003, China \\ ${ }^{b}$ Burapha University, Bangsean, Chonbury, 20000, Thailand \\ c Burapha University, Bangsean, Chonbury, 20000, Thailand
}

\section{APA Citation:}

Xiao, Y., Surasin, J., \& Prabjandee, D. (2020). Development of a training module to improve initial ELT proficiency among student-teachers in multi-ethnic community schools. Journal of Language and Linguistic Studies, 16(1), 366-389. Doi: 10.17263/jlls.712849

Submission Date:17/05/2019

Acceptance Date:26/02/2020

\begin{abstract}
This study aimed to investigate the current needs of student-teachers' professional development, develop a training module to improve their initial ELT proficiency and determine its effectiveness. The mixed methods research design with parallel strategy, starting with the quantitative and following by the qualitative research methods were employed in eliciting various sets of research data. Numerous instruments were utilized in different stages with 168 respondents (student-teachers and English teachers), 18 informants (parents, kindergarten English teachers, principles ans stakeholders) and 58 participants (student-teachers). The ADDIEM training process was adopted as a guideline for the framework to develop the training module. The study resulted in the following outcomes: 1) fourteen prioritized topics within the four transformed training modules (Linguistic Bases, Lesson Design, Teaching Techniques and Teaching Demonstration) were identified as the challenges facing the current studentteachers; 2) training objectives and its syllabus, lesson plans, instructional strategies, training participants and location, delivery of the training, and training evaluation and improvement were defined sequentially in each phase as the specific components of the training activities; and, 3) the ADDIEM Training Process, constituting of the six phases of need analysis, design, development, implementation, evaluation and modification, was merged systematically to develop a feasible training module, and the training program was highly accepted because of its effectiveness of great benefit and satisfaction. Finally, the constructive recommendations in view of focusing on establishing a pleasant teaching and learning environment, ensuring sufficient training periods, identifying the trainer's professional traits and competences, specifying trainees' background knowledge, altering training models at the in-service level were made for future practice and research.
\end{abstract}

C 2020 JLLS and the Authors - Published by JLLS.

Keywords: Training module; professional development; ADDIEM training process; ELT proficiency; multi-ethnic groups

\footnotetext{
${ }^{1}$ Corresponding author. Tel.: +86-134-6616-2286

E-mail address: youxingxiao@live.cn
} 


\section{Introduction}

As a multi-ethnic country, comprising of one majority Han group and other 55 ethnic minority groups, China is encountering problems of improving the quality and effectiveness of bilingual education for minorities. Postiglione (1999) indicated that the number and diversity of languages used by the non-Han peoples of China is a formidable barrier to the popularization of education in China's rural and remote frontier regions. Therefore, according to different languages used in bilingual education, normally it is distinguished into two categories in Chinese context, bilingual education for minorities and bilingual education for foreign languages ( $\mathrm{Li}, \mathrm{Liu}, \&$ Ghil'ad, 2014). The biggest obstacle to bilingual education in China is the lack of qualified teachers (Johnson \& Chhetri, 2002).

Teachers' low language proficiency has a direct impact on students' target language performance and language development. In an EFL context like that of China where English is neither the official language nor the language of daily use, language teachers and language classrooms may be students' only access to the English language, and teachers' modeling role is especially important in Chinese schools where teachers are the only English speakers and English classes are the only target language resources which students may encounter (Ahmed, 2011). Therefore, to master sufficient English language proficiency in order to provide target language models effectively has become one of the main concerns for teachers in China (Tsang, Yang \& Qiu, 2005).

Under the present context of such social status quo, Tan (2006) highlighted that the goal of bilingual teaching practice was difficult to achieve due to the lack of qualified bilingual teachers in initial levels, and not yet fully functioning professional training system for English teachers. Liu (2011) confirmed the same standpoint that the shortage of qualified bilingual teachers had become the main bottleneck restricting the development of bilingual education in kindergartens, the fundamental solution to the shortage of teachers should depend on training (Wang, 2012). Therefore, it was ideal to supplement and cultivate initial English teachers by strengthening the preschool and primary English education and curriculum to develop the formal and qualified English teachers by following the regulations of children' physical and mental development and special requirements of curriculum (Wang, 2007; Yao \& Li, 2010; Wang, 2012). Equally, it was urgent to cultivate qualified teachers and explore an effective pre-service training model for bilingual teachers (Zhu, 2007, Wang, 2012). As a professional department specialized in student-teachers' training, such colleges and universities should further hold the basic guidance of the student-teachers' professional level and development; also take in-depth research in pre-service training of English language teaching proficiency for beginning level (Wang, 2012; Gu, 2016). How to equip bilingual teachers with proficient language abilities and teaching proficiencies had become the focus of the teacher training and practice (Wang, 2007; Wang \& Mi, 2014). This teaching model was just consistent with the ultimate goal of initial English education in order to cultivate suitable talents for the development of the society; furthermore, for the current reform of the teaching model of English curriculum in professional initial education field. By using the teaching and training pattern, the professional pre-service training course could be combined with the English language course, which was in line with the trend of bilingual education and teaching (Wang, 2014).

\subsection{The ADDIE Training Model}

A number of instructional design models have been designed to guide the users in the instructional design process (Martin, 2011). According to Gagne et al. (2005), most systematic models of design had similar components, but could vary greatly in the specific number of phases and their graphic representations. The ADDIE model is one that contains five phases (analysis, design, development, implementation, and evaluation) (Clare \& Natalie, 2014). The solid lines indicated that the process flowed from analysis to evaluation and the dotted lines feedback pathways. Each ADDIE phase was 
purposeful and focused on the specific outcomes, and use of ADDIE model represented a dynamic, flexible guideline for building effective instructional material, it could provide a well-organized, strategic plan for training and instructional design that ensured quality through consideration of all of the elements (Gagne et al, 2005; Martin, 2011; Clare \& Natalie, 2014). Furthermore, the ADDIE Model, which contains five phases (analysis, design, development, implementation, and evaluation) was considered the most widely-used methodology of systematic training model and one of the most applicable-used effective instructional systems design models (Gagne et al, 2005; Reiser \& Dempsey, 2007).

In view of meeting uniformly rigorous standards for developing an individual and effective training, I highlighted the particular phase of Modification into the ADDIEM training process because it allowed me to optimize the use of the training model and promote more rewarding, and productive practice (Clare \& Natalie, 2014). Moreover, I essentially expected to identify further and detailed modifications and improvements of the training by combining the trainees' practical performances, real feelings and constructive suggestions, my original intention and reflective notes with the experts' feasible recommendations and the contextual documents and orientation. Correspondingly, the proposed ADDIEM training process which focused more on the specific outcomes included: Needs Analysis, training Design, training Development, training Implementation, training Evaluation, and additional training Modification. Different specific activities were organized and involved in each phase of the training process, which highlighted the core research problem of ELT proficiency to cater to the findings of study all the time (Clare \& Natalie, 2014).

\subsection{Research questions}

The study aimed at identifying the challenges facing the current student-teachers' initial ELT proficiencies, developing a training module to improve their ELT proficiencies and to determining its effectiveness. The following research questions were focused:

1. What are the challenges facing the current student-teachers in teaching English to beginning learners in multi-ethnic community schools in Yunnan Province?

2. What are specific components of training activities for student-teachers in teaching English effectively in multi-ethnic community schools in Yunnan Province?

3. How does the training process develop and to what extent does the training module improve student-teachers' ELT proficiency?

\section{Methods}

The present study was hybrid in its design, combining both quantitative and qualitative approaches during data collection and analysis phases of the study. Thus, the combination of research methods was likely to recur in each step of the training and development. Particularly, the study incorporated the convergent (or concurrent) parallel design (Creswell, 2012). Primarily aiming to explore the studentteachers' professional qualities, especially their initial ELT proficiency, both the quantitative and qualitative methods, with the same priority balanced, were conducted simultaneously at the first phase of the study.

\subsection{Participants and Instruments}

In terms of the quantitative research design, the sampling and participants selected from such convenient setting helped me gain a high level of insight about the actual situation (Creswell \& Clark, 
2011). The population of the study was mainly student-teachers (including both bachelors and masters), majoring in pre-school education and primary school education, who were studying in current campus of Dali University, and others were mainly teachers who had some certain English teaching experiences in different schools. Due to the number of participants being very large, the purposive sampling procedure was selected by using a gate keeper technique to provide valuable information related to the research questions (Teddlie \& Tashakkori, 2009). Factually, there were 168 participants involved in the questionnaires. $152(90.48 \%)$ student-teachers in 2015 academic grades joined the first set of questionnaire while other 16 (9.52\%) English teachers took part in the second set of questionnaire. Among 152 student-teachers in the first cohort, 126 (75\%) were bachelors and $26(15.48 \%)$ were masters who were both majoring in preschool education and in current campus of Dali University. In the second cohort, out of 16 English teachers, 11 (6.55\%) were kindergarten English teachers, 2 (1.19\%) were primary English teachers, and the other $3(1.78 \%)$ were middle school English teachers. Two sets of self-administered questionnaires, aiming at identifying the possible challenges for the phase of training need analysis and specific components in developing ELT proficiency training module, were employed for these two groups.

With regard to the qualitative research design, the informants chosen purposively were invited to participate in the interviews. The number of informants was determined by completeness or saturation of the information provided by a given number of participants. The saturation of the information would occur when no more new information was learned from participants (Rubin \& Rubin, 1995). Finally, 5 (27.8\%) English teachers working in kindergartens around Dali city, 2 (11.1\%) administrators in Faculty of Education of Dali University, 3 (16.7\%) stakeholders in bilingual kindergartens, and $8(44.4 \%)$ parents involved in bilingual kindergartens, closely to my proximity, were confirmed to take different interviews. Thus, three different sets of semi-structured and open-ended interviews were provided to voice their perspectives and share their values about English teaching proficiency from the involved English kindergarten teachers, administrators and stakeholders, and parents.

Both the questionnaires and interviews were conducted particularly in the Needs Analysis phase of training, another additional participants were enrolled from the target student-teachers in 2016 and 2018 academic grades as the real trainees in the Development Phase of training. The estimated number of the additional participants needed to conduct statistical tests with sufficient power result was only 45, calculated by using the G*Power Software (Erdfelder, Faul, \& Buchner, 1996). But finally, actual 58 participants were identified by using volunteer sampling technique. More active volunteers still applied for enrolling the training group but were refused with consideration of the training effectiveness. The 58 participants engaged in the practical course training and were expected to provide useful feedbacks and suggestion upon the effectiveness of the training. The following table displayed the basic information of classification of the trainees. The 58 participants were selected from 2 academic grades of 8 different classes in bachelor and master program, mainly majoring in preschool education and primary school education, and then coded (see Table 1). In the later Implementation and Evaluation Phases of training, surveys, classroom observations, teaching logs, artifacts, pretest and post, and reflective journals were employed. 
Table 1. Basic Information of Classification of the Trainees $(\mathrm{N}=58)$

\begin{tabular}{lllll}
\hline Codes of Range & Number & Grades \& Classes & Majors & Levels \\
\hline $1-10$ & 10 & Grade 2016, class 1 & Pre-school education & Bachelor \\
$11-13$ & 3 & Grade 2016, class 2 & Pre-school education & Bachelor \\
$14-21$ & 8 & Grade 2016, class 3 & Pre-school education & Bachelor \\
$22-29$ & 8 & Grade 2016, class 4 & Primary school education & Bachelor \\
$30-35$ & 6 & Grade 2018, class 1 & Pre-school education & Bachelor \\
$36-44$ & 9 & Grade 2018, class 2 & Primary school education & Bachelor \\
$45-50$ & 6 & Grade 2018, class 3 & Pre-school education & Master \\
$51-58$ & 8 & Grade 2018, class 4 & Primary school education & Master \\
\hline Total & 58 & 2 grades, 8 classes & 2 majors & 2 levels \\
\hline
\end{tabular}

\subsection{Data Collection and Data Analysis}

The purposes of the study aimed at seeking different perspectives from student-teachers and tried to construct the training module to develop their ELT proficiency in such case of context. The present study was congruent with Creswell (2009) to collect all the data from the questionnaires, pre-post tests, interviews, class observations, reflective notes and documents. In this convergent design, after collecting both quantitative and qualitative data concurrently, I used parallel construction for both types of data to assess information; separately analyzing both types of data; and then merging the two databases, comparing results through procedures such as a side-by-side comparison in a discussion, transforming the qualitative dataset into quantitative scores, or jointly displaying both forms of data (Creswell, 2012). The merging approach had also been called simultaneous integration (Morse \& Niehaus, 2009), so I illustrated a close relationship among the research questions, data collection and analysis to show how these three aspects were integrated together. There were three items of research questions in the first column, the second column was about how the data were collected by both quantitative and qualitative methods, and in terms of the third column presented how the data were analyzed systematically. Simply speaking, each item of research questions could be interpreted in corresponding linkage of data collection and analysis (see Table 2).

Table 2. Linkage between Data Collection and Data Analysis

\begin{tabular}{lll}
\hline Research Questions & Data Collection & Data Analysis \\
\hline 1. What are the challenges facing the current & - Questionnaires & - Descriptive Statistics \\
student-teachers in teaching English to & - Interviews & - Transcription \& Interpretation \\
preschoolers in multi-ethnic community & - Personal Experiences & - Comparison \& Examination \\
schools in Yumnan Province? & - Documents & - Documentary Analysis \\
\hline 2. What are specific components and contents & - Interviews & - Transcription \& Interpretation \\
of training module for student-teachers in & -Questionnaires & - Descriptive Statistics \\
teaching English effectively in multi-ethnic & - Class Observations & - Videotaped Observations \\
community schools in Yuman Province? & - Artifacts/ Documents & - Artifacts / Documentary Analysis \\
\hline 3. To what extent does the training module & - Surveys & - Descriptive Statistics \\
improve student-teachers ELT proficiency? & - In-depth Interviews & - Transcriptions \& Interpretation \\
& - Pretest \& Posttest & - Comparative Analysis \\
& - Class Observations & - Videotaped Observations \\
& - Reflective Notes & - Interpretation \\
\hline
\end{tabular}

All in all, both quantifying qualitative data and qualifying quantitative data were adopted according to Creswell (2012). On one side, different themes and categories were extracted from the qualitative data, and then were coded and classified with assigned numbers. Quantitative data were descriptively analyzed for frequency of occurrence. On the other hand, quantitative data from questionnaires were 
factor analyzed. These factors then became themes that were compared with themes analyzed from qualitative data. Specifically, I proposed frequency/descriptive statistics, one-sample t-tests to interpret quantitative results, and qualitative data analysis utilized three-steps coding process consisting of thematic coding, pattern coding, and triangulation. This dual data analysis procedure in the mixed methods was utilized to capture multiple perspectives to develop a more complete training module of the ELT proficiency in such a context.

The goal here was to triangulate the findings from the two forms of data. Triangulation of the two sets of findings served to validate both the qualitative and quantitative findings. Data were collected through multiple sources that included the questionnaires, interviews, classroom observations, documents and my own reflective notes, so the techniques of triangulation strengthened the design by integrating the data collected from all sources. Thus, the results were corroborated with interview data, and the use of interview and observation to validate through questionnaires (Creswell, 2009).

\section{Results and Discussions}

The proposed and adapted ADDIEM training model, constituting by six different phases (Need Analysis, Design, Development, Implementation, Evaluation and Modification), run through the whole research process of the study, which kept the close consistence with the research design by using the mixed quantitative and qualitative research and data. Based on the three research questions of the study, I constructed the detailed framework within the training process in order to lead and maintain the integrity of the training and development process (Richard \& Elwood, 2009). Each training phase consisted of several steps and activities which led me to develop the course training and conduct all activities systematically. Therefore, each finding extracted from the different training phase was respectively presented by the following sections.

3.1. Findings of the $R Q 1$ "What are the challenges facing the current student-teachers in teaching English to beginning learners in multi-ethnic community schools in Yunnan Province?"

The intended needs were investigated from the student-teachers and the possible expectations were summarized from the kindergarten English teachers, principals and stakeholders, and parents based on both quantitative and qualitative analysis, finally 14 topics of proposed challenges which were highly rated with the percentage and frequency were refined and indentified in the Needs Analysis phase of the training. 


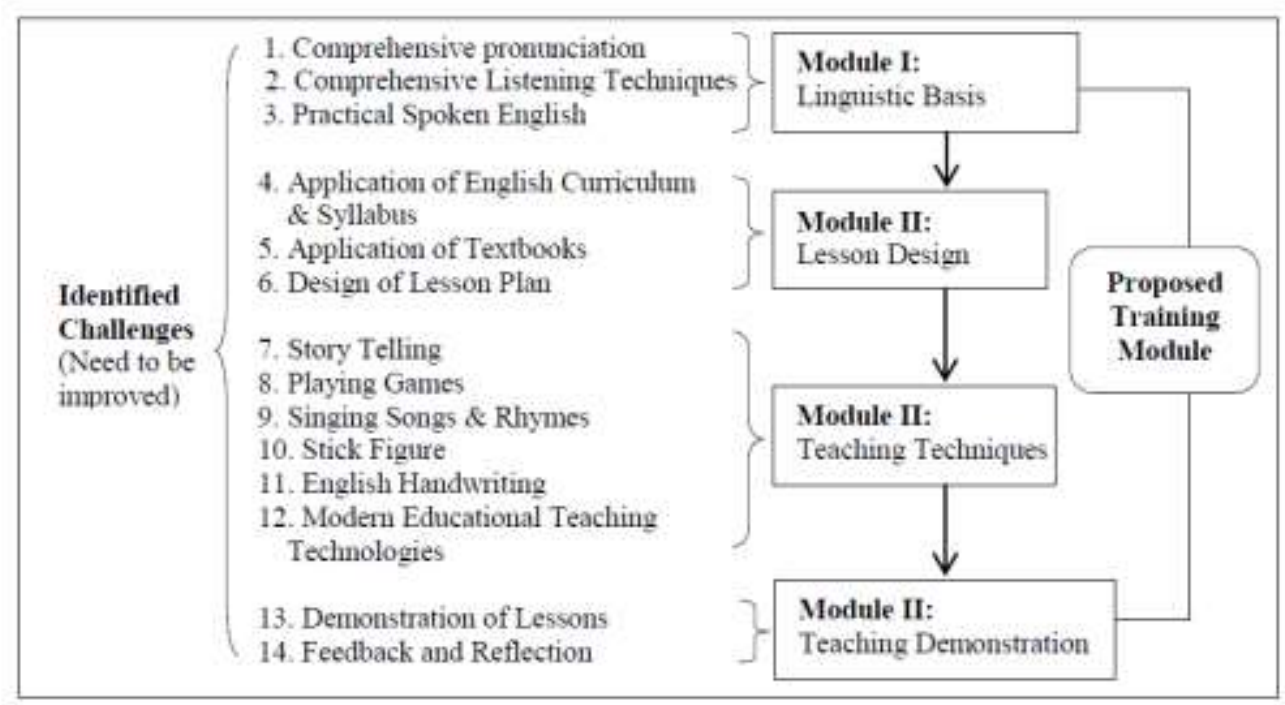

Figure 1. The Developing Interrelation between the Identified Challenges and the Proposed Training Modules

Conclusively, a developing interrelation between the 14 identified challenges and the relevant 4 proposed training modules were displayed as shows in Figure 1. This developing interrelation played a critical guiding role for the following systematic phases of the training process based on the three following regards: 1) the conclusive categories of codes and themes extracted from the questionnaires and interviews; 2) my personal experiences and present understanding about the situation; and 3) the relevant research reviews and references. In terms of the initial ELT proficiency in the context of current educational situation, especially English teachers' pronunciation, spoken English and listening ability were ubiquitous and problematic issues in performing in the practice (Tan, 2014; Wang \& Mi, 2014). Similarly, it was difficult to design and organize good English teaching activities much less to include the development of integration in bilingual curriculum based on my own teaching experiences in previous ELT practice for both preschool and primary education majors (Shen \& Zhao, 2010).

Additionally, it should be classified that some certain items extracted from data, such as vocabulary, grammar, knowledge of British \& American cultural background, knowledge of cross-cultural communication, reading ability, and writing ability at the same time were not included in the present study even though holding their equivalent rates of percentage scores, but it did not absolutely indicate that they were not important or necessary for student-teachers' general ELT proficiencies. There were some reasons as follows:

1) In the critical period of language learning for children, its advantage was to build a corresponding language environment by imitating of the voice and intonation to form the language sense naturally; and learning pronunciation well as the most important and basic factor in language acquisition, which also need to obtain a lot of language input of listening (Li, 2006; Wang, 2009);

2) Teaching English to Children emphasized on not the amount of vocabulary, but the ability of learning English and using it. If it was just the number of words we were valuing for, they would be in a negative state sooner or later (Wang, 2016);

3) Gimson (1962, cited in Wang, 2009) stated when a person spoke a language, he/she had to learn almost $100 \%$ pronunciation of the language, while he/she just need to learn 50 90\% grammar and 1\% vocabulary. Phonetic learning directly affected the ability of oral expression and listening comprehension ability for the children's development, while reading and writing abilities were not emphasized in early stage; 
4) Compared with adults, childhood was a key implicit period of learning, and the huge deformability of speech, strong imitative ability and reproductive ability could easily form the good pronunciation and intonation, which had great advantages in second language acquisition (Tian, 2007);

5) Last but not least, such as the knowledge of British \& American cultural background and crosscultural communication, they were relatively hard to be examined and indentified within such a limited training period especially for those who were non-English majors and not to mention their current lower situation of ELT proficiency.

\subsection{Findings of the RQ 2 "What are the specific components of training activities for student- teachers in teaching English effectively?"}

It was considered as the biggest part because each finding generated from each training phase might be the indispensable sub-sections for the specific components of the training processes and activities. Therefore, based on the elaborations of identified challenges provided in the Needs Analysis Phase, the immediate identified outcomes from the training Design Phase, the training Development Phase, the training Implementation Phase, the training Evaluation Phase, and the training Modification Phase were merged sequentially to answer the research question in respect of the specific components of training activities.

The general goals of the proposed training course aimed at improving basic professional qualities and practical teaching skills which were based on ELT proficiency at the beginning level for current student-teachers to optimize their pre-service professional development towards the specific objectives. The specific training objectives in the phases of the training modules were developed, revised and finalized in order to reflect realistically the necessity of the training. On one side, each item of the specific objective was derived from and identified by the quantitative and qualitative data during the phase of need analysis; on the other side, the suitability of the objectives was also considered based on the practical levels of the current student-teachers' expertise which was expected them to achieve under the parallel analysis of the present context. Therefore, corresponding instructional delivery and assessment criteria were determined at such 1-3 levels of Knowledge, Comprehension and Application by making a reference to Bloom's Taxonomy of cognitive domains (Huitt, 2011), which was oriented to be adequate and appropriate for them so far. That is, all the items of outcomes were determined as the specific objectives serving for each phase of the training modules, and the degree of difficulty, the relationships between objectives also were overall reflected. In sum, several different activities performed sequentially in different phase of the ADDIEM training process initiated different outcomes, which constituted the specific components of the training processes as demonstrated in following Table 3.

Table 3. Phases, Activities and Outcomes within the ADDIEM Training Process

\begin{tabular}{llll}
\hline Main Phases & Specific Activities & Major Outcomes \\
\hline Need Analysis & - to design and conduct the questionnaires and interview & -identified challenges \\
& - to consider characteristics of the training context & \\
& - to interpret and identify student-teachers' needs & & \\
& - to take an inventory of available training materials and & & \\
& resources & & course \\
& - to select appropriate instructional models of training & & -designed \\
\hline Training Design & - to distribute course modules & objectives and & course \\
& - to construct instructional framework & syllabus & \\
& - to set course criteria of assessment & & \\
& - to define detailed contents and activities & & \\
& - to employ instructional techniques & & \\
& - to draw a tentative schedule & & \\
\hline
\end{tabular}




\begin{tabular}{|c|c|c|}
\hline $\begin{array}{l}\text { Training } \\
\text { Development }\end{array}$ & $\begin{array}{l}\text { - to design } 14 \text { different lesson plans } \\
\text { - to select appropriate materials and tools } \\
\text { - to determine a proper criteria of evaluation } \\
\text { - to develop assessment instruments } \\
\text { - to enroll trainees and provide training guides } \\
\text { - to make schedules and locate a classroom }\end{array}$ & $\begin{array}{l}\text {-prepared lesson plans and } \\
\text { instructional strategies }\end{array}$ \\
\hline $\begin{array}{l}\text { Training } \\
\text { Implementation }\end{array}$ & $\begin{array}{l}\text { - to state current teaching and learning experiences } \\
\text { - to make full of preparation } \\
\text { - to carry on the real training activities } \\
\text { - to observe the classroom } \\
\text { - to conduct survey questionnaires } \\
\text { - to collect participants' feedback }\end{array}$ & $\begin{array}{l}\text {-purposive recruitment of } \\
\text { trainees } \\
\text {-successful delivery } \\
\text { training course }\end{array}$ \\
\hline $\begin{array}{l}\text { Training } \\
\text { Evaluation }\end{array}$ & $\begin{array}{l}\text { - to select appropriate techniques of measurement } \\
\text { - to conduct the formative evaluation } \\
\text { - to conduct the summative evaluation } \\
\text { - to conduct final post-test evaluation } \\
\text { - to interpret training effectiveness }\end{array}$ & $\begin{array}{l}\text {-complete formative and } \\
\text { summative assessments }\end{array}$ \\
\hline $\begin{array}{l}\text { Training } \\
\text { Modification }\end{array}$ & $\begin{array}{l}\text { - to review reflective notes } \\
\text { - to extract data from the survey and questionnaires } \\
\text { - to interpret data from class observation } \\
\text { - to review trainees' assignments } \\
\text { - to interview some certain trainees }\end{array}$ & $\begin{array}{l}\text {-identified improvement } \\
\text { and modification }\end{array}$ \\
\hline
\end{tabular}

Determining general training goals, defining specific training objectives and organizing training activities were more often than not critically essential and particularly important consideration in training design and development to create a satisfying and effective learning experience (Brown \& Green, 2016, p.102). Equally, the course syllabus generated from the training design phase, was considered as the critical and essential component based on Nation and Macalister's statement (2010). "A negotiated syllabus involves the steps of 1) negotiating the goals, content, format and assessment of the course, 2) implementing these negotiated decisions, 3) evaluating the effect of the implementation in terms of outcomes and the way the implementation was done (p. 150)" The following elements were "negotiated" in order to make the syllabus workable and effective, they were: negotiation procedures, course planning (for participation, procedure, and goals), course evaluation, and resources and materials (Nation \& Macalister, 2010). That was just as the key rationale of the course syllabus design of the training process; and the above-shown course syllabus was negotiated to provide such a changeable instructional model for the following phase of training development.

Additionally, with the higher emphasis on constantly increasing flexibility and accountability for the current student-teachers' learning, the most successful instruction was that which resulted in growth and achievement for all the students. "It would seem that using systematic processes to ensure that the identified needs of students direct all instructional decisions would be the most productive approach"(Clare \& Natalie, 2014, p.28). However, there was no a ready norm which could be applied for such a context of the study; consequently, I designed a proposed instructional model "3Ps + 2Ds" as a referential instructional design framework by considering maximizing identified challenges for all the student-teachers in such a context. The "3Ps +2 Ds" instructional model here referred to the following 5 abbreviations: Preparation, Presentation, Practice, Demonstration and Discussion, which were placed sequentially as the main body of each lesson plan. The proposed "3Ps $+2 \mathrm{Ds}$ " instructional model was expected to help 1) clarify the goals for training, 2) identify training decisions on known trainees' needs, 3) locate and choose appropriate training resources, and 4) understand the effect of the training materials or methods, and so on (Clare \& Natalie, 2014, p.32).

With regard to another important outcome of the component, Serdyukov and Ryan (2008) expressed that "good lesson plans are the foundation of successful student learning, accurate assessment, and 
effective classroom management" (p.1). The development of 14 copies of lesson plans according to the 14 topics of the identified challenges was also a critical stage in the training design phase. The welldesigned lesson plans helped set the sound implementation of the training program, and they also displayed a signal that such training was to be conducted in a professional manner (Serdyukov \& Ryan, 2008). Therefore, once the specific training objectives and course syllabus had been designed in preceding phase, the modular lesson plans should be organized and prepared to outline the training program in terms of the sequence of activities and events, and to guide for the trainer that provided a step-by-step breakdown for conducting the sound training program (Serdyukov \& Ryan, 2008).

The model of lesson plan here might vary from other situations, but it shared the three common and essential features of a complete, well-organized lesson plan: objectives, procedures, and evaluation (Eby, Herrell \& Hicks, 2002). The lesson objectives specified the training purposes, the lesson procedures described both "what training experiences can be provided" and the way which could be "effectively organized", while the lesson evaluation described the way I had planned in advance to determine "whether these purposes are being attained" (Eby, Herrell \& Hicks, 2002. p.145). An available wellprepared and individualized instruction facilitated me to ensure that the products (all drafts of lesson plans) to be responsive to the needs of trainees and effective in achieving the desired training outcomes (Dick, et al, 2005, p.10). Accordingly, such instructional strategies/models/techniques: problem-based learning, open-ended learning, directed learning, cooperative learning, concept-attainment model, inductive learning, authentic teaching, simulations and games, and individualized instruction, and so on, were consulted, developed and embedded in different lesson plans in order to work best based on the trainees' needs and the training goals and objectives.

Moore (2015) stated the evaluation served many roles in the teaching-learning process, and it should not be limited to only the 'desired outcomes' but also must be "sensitive to all factors" potentially associated with the whole course of the training (p. 251). Consequently, all the outcomes of components generated from the preceding phases including the identified needs, the specific objectives, the negotiated syllabus, the selected instructional strategies, the designed materials, the prepared lesson plans, the enrolled trainees, and even the confirmed classroom, etc, were addressed again by guiding a dynamic and flexible evaluation system (Moore, 2015). I must be sensitive on all the potential or possible instruments of measurements associated with the whole training process, and that's the main reasons why the following primary evaluation types: pretest, formative and post-test (summative) were applied into different phases of the training process by its natural and chronological position in terms of their special characteristics and purposes.

All in all, understanding the organization of training events, the determination of scope and sequence, the placement of teaching and learning experiences, the preparation of training course syllabus and lesson plans, the description of delivery method and the application of evaluation criterion helped me identify what was necessary to create the specific components of training activities that was effective for a variety of student-teachers - from the average one to those who required either more support or greater challenges (Brown \& Green, 2016, p.113).

\subsection{Findings of the RQ 3 "How does the training process develop and to what extent does the training module improve student-teachers' ELT proficiencies?"}

One of the main purposes of the study was to develop a feasible training module to improve initial ELT proficiency among student-teachers in such a setting, so I developed the interrelated ADDIEM Training Process which involved into the core research problem of ELT proficiency as shown in Figure 2 , it was applied to "lead and maintain the integrity of the training and development process" (Richard \& Elwood, 2009, p. 244). The proposed systematic framework was exhibited as a training blueprint throughout the whole ADDIEM training process. Combining the specific training process with the 
identified components of training activities again illustrated how the training process was developed effectively and systematically.

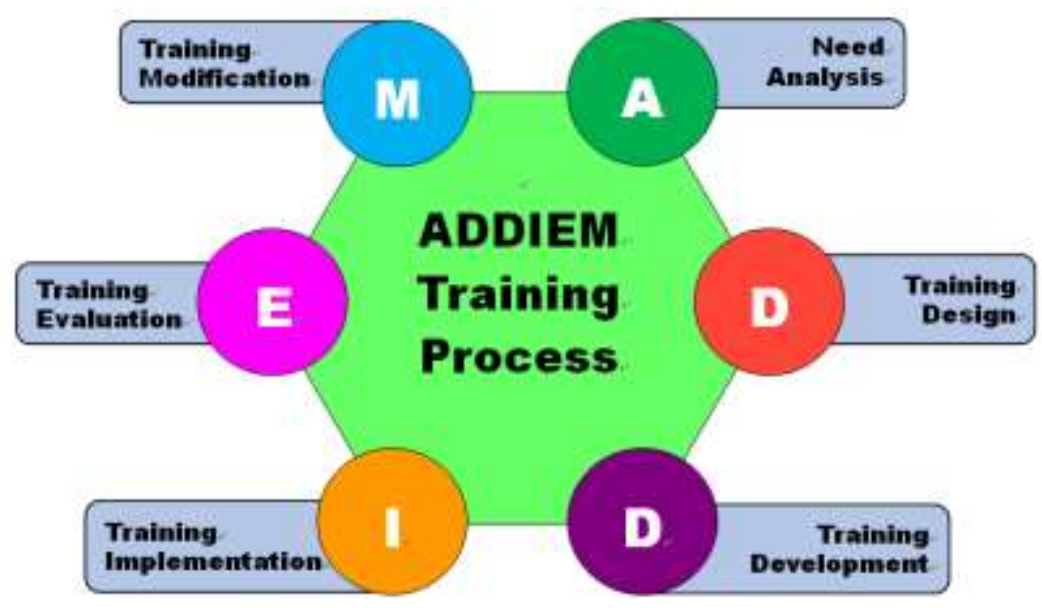

Figure 2. The ADDIEM Training Process

(Source: Adapted from Richard \& Elwood, 2009).

\section{From the Trainees' Feedbacks}

With regard to overall improvement for the trainees' ELT proficiency upon the training module, the results obviously indicated a high and positive consistency from the data analysis of the training process. $100 \%$ trainees expressed their affirmative certainty of "feeling beneficial from the whole training to a great extent". When asked "what percentage of your original expectation is based on the training content?" $7.03 \%$ of the trainees compared with their original expectations in the scale of $60 \sim 69 \%$, $20.28 \%$ was in the scale of $70 \sim 79 \%, 42.03 \%$ was in scale of $80 \sim 89 \%$, and $30.66 \%$ was in the scale of 90 100\%. Majority of the trainees expressed pleasantly that they had gained what to expect and reached basically their learning targets. Certainly, a few of the trainees reported the training did not meet their personal learning targets, nevertheless, they explained a factual and understandable issues because of "the limited training periods". Furthermore, a higher percentage from the survey in terms of the training course practicality displayed $72.34 \%$, and another comparison of the trainees' proficiency from the evaluation forms of satisfaction also showed that $27.66 \%$ of the trainees felt not satisfied with their current proficiency, $46.81 \%$ felt just so so before the training, but after the training, $2.13 \%$ felt not satisfied, $19.15 \%$ felt just so so, $48.94 \%$ felt basically satisfied, $25.52 \%$ felt satisfied, and $4.25 \%$ felt very satisfied, which indicated the training modules also produced an positive orientation of improvements for the student-teachers. Such data extracted from the multiple sources including the questionnaires, interviews, classroom observations, documents and my own reflective notes exactly served to validate both the qualitative and quantitative findings in terms of triangulation. That was to say, the techniques of triangulation strengthened conversely the reliability and validity of the results (Creswell, 2003).

With regard to the specific improvements, the main categories from high to low frequency coded from the original data by revising, rereading and adjusting several times, such as: advanced the trainees' learning interests and confidence, improved comprehensive English pronunciation, improved practical spoken English and comprehensive listening ability, well-acquired applying skills and techniques upon general instructional design, and self-reflected awareness of disadvantages were respectively displayed in an existing high-low frequency as the specific aspects of improvements of the student-teachers' ELT proficiency. 
-Category I: Advanced Learning Interests and Confidence. The student-teachers firstly expressed their higher frequent feeling about advancing strong interests and confidence by asking the question of "what did you gain mainly from the topics of the training modules?" after training. Interest and confidence, belonging to the non-intelligence factors which played a crucial role in fulfilling the individual needs of language learners, were highlighted normally to raise the awareness of students' individual learning styles by arousing their potentialities in learning a target language and by enabling students to be in charge of their own learning (Pintrich \& Schunk, 2002). Such aspects of the improvements recognized by the student-teachers themselves, conversely, might stimulate their own positive motivation to achieve and to cultivate their senses of achievement in acquiring more ELT proficiency (Li, 2015).

-Category II: Improved Comprehensive English Pronunciation. The coming aspect of improvements of the student-teachers' ELT proficiency was that the training improved their comprehensive English pronunciation from the linguistic basis of the training module to some extent. More than a dozen of participants affirmed that they could pronounce better comprehensive pronunciation after reviewing phonetic symbols and practice. Pronunciation was deemed the most important and difficult problem that non-native English majors had to face when studying English, even though they had had at least more than ten years of English education based on the current situation with traditional teacher-centered instruction of Chinese ELT proficiency (Fraser, 2000; Zeng, 2008; Li, 2014). According to Harmer (2001), lack of high quality, suitable teaching and learning materials, and lack of time to practice pronunciation were the major reasons that cause lower attention to English pronunciation, so I intended to expose the authentic materials, an internet-linked APP software (Phonetic Symbols Clicking and Reading Cards) which could be operated by a mobile phone whenever and wherever possible to help the student-teachers practice their pronunciation (Rasekhi, 2010). I just acted as a speech coach of pronunciation, gave feedback to them, and encouraged them to improve their pronunciation during the implementation of the training module inside and outside the classroom (Thanasoulas, 2002). The student-teachers also remarked that improper pronunciation could lead to negative impression, misunderstanding and ineffective communication (Hope Speak, 2014).

-Category III: Improved Practical Spoken English and Listening Ability. Listening and speaking were the essential skills which often affected the development of reading and writing abilities in learning language (Yavuz \& Celik, 2017). According to Phil (2007), both speaking and listening need to be especially and purposefully trained in order to become a well rounded communicator. The traditional approaches of language teaching and learning, like the Grammar Translation Method, failed to properly care for the speaking and listening skills in the majority of classrooms where emphasized mainly on reading and writing skills (Kaddour, 2016). Furthermore, exactly as Janice (2017) stated neither listening nor speaking would occur in isolation. Hence, each one relied on the other to succeed a conversation through interacting and negotiating verbally. In conclusion, one of the common instructional objectives identified in these two topics of the training module was to expect the studentteachers to apply frequently-used communicative expressions and classroom terminologies and to follow frequent instructions in daily activities based on the analysis of their prior knowledge and practical experiences in such a setting of the study. Recommended by Hosni (2014), some oral activities in the form of simple songs, rhymes, chants, games, stories and other conversational interactions were employed in the training module to enable the student-teachers to have more fun and enjoy learning to improve effectively their listening and speaking skills. I accordingly designed a plenty of activities related with listening and speaking, which was not only performed in these two lesson plans, but also covered in other topics during the whole implementation of training module. Compared with their prior knowledge and practical experiences existing in the daily English learning and teaching, it was congruent that the student-teachers' difficulties in learning English attributed to be shy of their limited 
vocabulary and be afraid of making mistakes in front of the class (Farooqui, 2007). Some of the studentteachers confessed unhesitatingly that they just were such potential issues as simply shyness, nervousness, feeling afraid of making mistakes, not knowing the way how to pronounce certain words, having lower motivation or uneven participation that hindered them involving in the active and effective interactions (Ur, 1996; Rahman \& Deviyanti, 2012). Some factual evidences from the classroom observation showed that few student-teachers kept dumb or in a low mood while engaging in the interactions all the time exactly because of above-mentioned factors. Thus, giving more patience, allowance, especially encouragement could be induced as my individual instructional techniques or characteristics from the whole implementation of the training module; after all, encouraging the studentteachers to practice more aimed at putting with an eye towards their practical improvement (Kaddour, 2016).

-Category IV: Well-acquired Application of Techniques upon Instructional Design. Apart from the specific improvements of the student-teachers' ELT proficiency in respect of the linguistic basis of the training module, most of the other aspects of improvements were closely related with and attributed to the Instructional Design (ID). On account of the coded results from the training module, the participants expressed in succession that they benefit to know more about instructional design from the training. Consequently, the ID could be said to be a system of creating the more specific procedures or approaches for design, development, evaluation, maintenance and modification of instructional recourses and materials that facilitated the more effective and efficient learning and performance (Richards \& Lockart, 1994; Gustafson \& Branch, 2002; Martin, 2011).

Some of the participants also realized the importance and necessity of the instructional design. Generally speaking, instructional design was a system of developing well-structured instructional materials, using identified objectives and related teaching strategies, applying appropriate curriculum syllabus and textbooks, organizing well-prepared lesson plans, selecting proper teaching techniques with technologies, launching systematic feedback, reflection and evaluation (Moore \& Kearsley, 1996).

A few participants also highlighted the teaching and learning resources and materials provided in and out of the class. The teaching and learning resources and materials also played a crucial to the success of student-teachers achievement and improvement in a way. One of the indispensible instructional components of lesson planning in teaching depended on the identification of teaching and learning resources and materials which could not only significantly increase student-teachers achievement but also add important structure to lesson planning and the delivery of instruction in the training (Hassan \& Miraclea, 2009). Based on Hassan and Miraclea (2009), such properties of being educative and relevance were prioritized and determined by the identified objectives of the training module, various forms of the teaching and learning resources and materials, including audio-visuals, videos, hand-made cards, pictures, worksheets, tutorials, linkages of networks, online books and articles, blogs, publications, charts, templates, maps, cases, screenshots, even WeChat public accounts, and so on, were distributed in accordance with the different activities in present training modules. In sum, the authentic and effective resources and materials were applied to provide scaffolding for learning, stimulating the feedback and reflection, arousing and sustaining the curiosity and attention, enhancing the learning opportunities, promoting the input and output, enlarging the understandings of language, and activating intellectual emotional involvement (McGrath, 2002; Tomlinson, 2003; Hassan \& Miraclea, 2009; Martin, 2011).

-Category V: Self-reflected Awareness about Their Own Disadvantages. A few student-teachers reflected faithfully that the training let them know their own shortages and weaknesses. As a result, they realized that they should make more efforts on the improvement of the following general aspects, such as English pronunciation, practice about spoken English listening comprehension, practical knowledge of communication and classroom expressions, poor vocabulary, low sensitive in listening, both sections 
of presentation and evaluation in an instructional design, excellent learning and teaching methods and techniques, flexible application of textbooks, overcoming of nervousness, impatience, inferiority, lazy and timidity, and so on. As Confucius said, "by three methods may we learn wisdom: first, by reflection, which is the noblest; second, by imitation, which is the easiest; and third, by experience, which is the most bitter". The student-teachers' self-reflective awareness about their own disadvantages and weakness increased the motivation and participation to effectively address the identified challenges and prepare for their social practice conversely, which allowed space for their future growth and learning (Zimmerman, 2002; Mann, Gordon \& MacLeod, 2009; Jordi, 2011). The importance of reflection and reflective practice were frequently noted in the literature; indeed, reflective capacity was regarded not only as an essential characteristic and necessary component for successful professional development, but also as an important continuum to engage in personal self-reflection and correction toward the development of professionalism (Mann, Gordon \& MacLeod, 2009; Copeland \& Oliphant, 2014). The student-teachers' self-reflection in identifying their personal errors and making evidence-based decisions were closely involved in their learning processes, whereas self-awareness became one of the identified objectives of the training process (Elder, et al., 2007). On the other hand, transitioning from the teacher-centered classroom model to a student-centered approach could also focus more on selfreflection, self-understanding, and transformative education (Silverman, 2008; Rosin, 2015).

In summary, it should be highlighted that one of the components of "emotional intelligence" identified by Goleman (1996, cited in Graf \& Birch, 2009, p.21) was self-awareness, which maintained the more importance to successful and effective learning than traditional intelligence. Developing this emotional intelligence of learning or arousing the student-teachers to become "emotional intelligent" in the practical training process of ELT proficiency just coordinated completely with the identified objectives of the training module. It was obviously of great importance to urge every student-teacher to "feel emotionally secure and psychologically safe" in order to require such self-reflective processes and self-aware practice in the overall curriculum design and the effective course training (Ginnis, 2002, cited in Graf \& Birch, 2009, p.26).

\section{From the Trainees' Feedbacks}

In terms of my personal perspective as the trainer of the training, I could objectively draw a conclusion that the whole implementation of the training was positive instrumental for the studentteachers' overall professional development based mainly on my reflective notes, classroom observation and the student-teachers' feedbacks. The following aspects might evidence the student-teachers' obvious improvement of ELT proficiency with regard to the two certain practical assignments.

Firstly, as discussed in RQ 2, it was indentified that some certain improvements attained from viewing the trainees' manuscripts of English by comparing the "entry point" pretest and the "exit point" posttest based on the practical training under the special area of English handwriting, majority of the trainees basically framed the identified objectives of writing English letters formation more legible and more fluent by applying the basic writing skills and techniques in the certain training component of teaching techniques (Eby, Herrell \& Hicks, 2002). The following Figure 3 demonstrated as a scanning sample of one trainee's English manuscript in both pretest and posttest sides. 


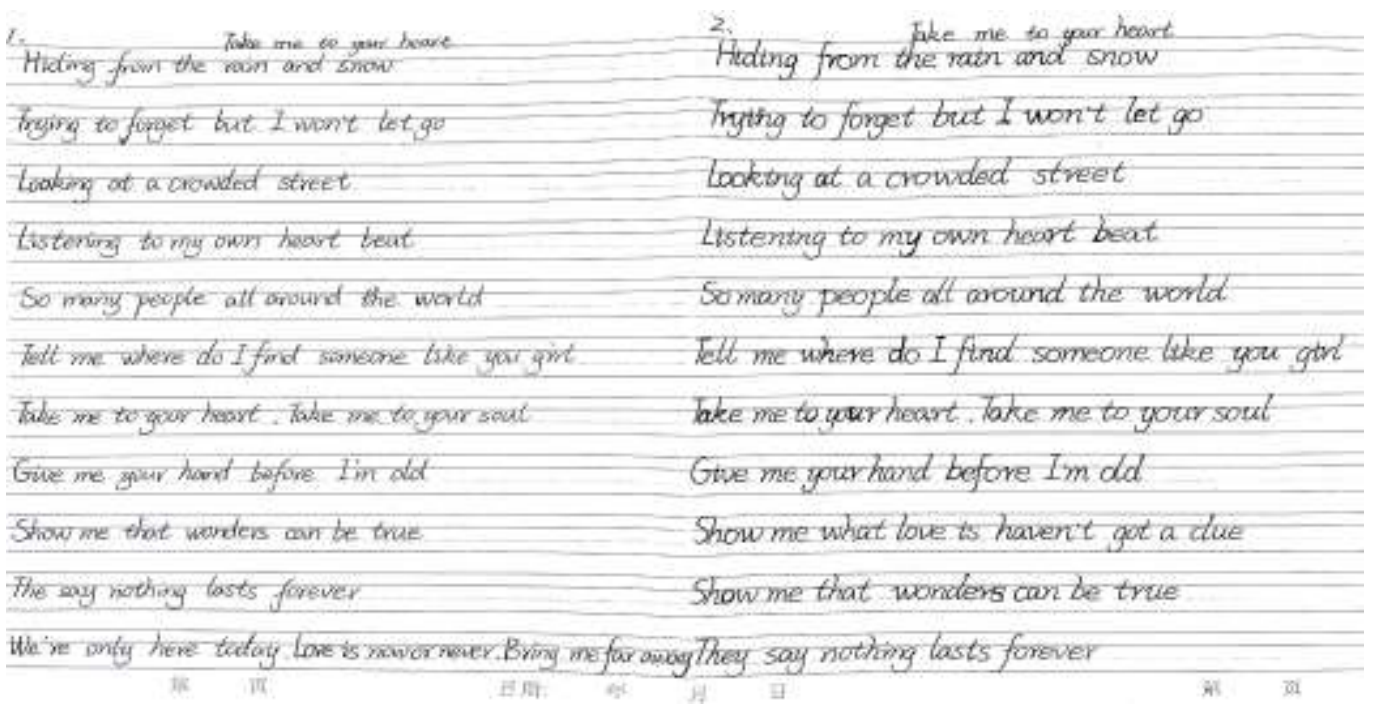

Figure 3. A Scanning Sample of One Trainee's English Manuscript

According to Spinelli (2011), I mainly assessed the student-teachers' handwriting legibility (the clarity and readability of handwriting) and fluency (the rate of written production) by observing and analyzing their writing samples. At the same time, by consulting the Zaner-Bloser Evaluation Scale which was a holistic method of assessing manuscript, I determined whether the student-teachers' handwritings were significantly below average, average, or above average when compared with grade norms which highlighted the five main visual features as handwriting legibility components: letter form, alignment, size, spacing and slant (Amundson, 2005; Feder \& Majnemer, 2007; Hadavandkhani, et al., 2008; Spinelli, 2011, p.113). Regardless of increasing accessibility and dependency on modern electronic communication devices which had made communicating more universal, the ability to write and develop much legible and fluent handwriting remained the most important daily task especially for all levels of students (Santangelo \& Graham, 2016). However, based on my individual long-term experiences of teaching Chinese calligraphy in the current setting of the study, the factual situation was that I hardly bear the sight of the majority of students' illegibility and less-fluency of Chinese handwriting, not to mention their English handwriting even in some cases of English majors. The legibility (or illegibility) of children's handwriting in the beginning level of learning was frequently determined by their first teachers (Tseng, 1998). Letter formation was shown to be a key contributor to overall handwriting legibility in primary aged children. Consequently, for the student-teachers in a normal university, mastering the ability to produce well-formed letters seemed an imperative and important competence for developing legible handwriting and successful completion of many classroom activities. While for children developing handwriting skills, improvements in all five legibility components above-mentioned would presumably improve the overall acceptability of handwriting to the student-teachers (Janes, 2018).

Another daily assignment was the lesson plan named We Love Animals designed by the trainees after delivering the 6th area of instructional design of the training. Similarly based on my personal teaching experiences, I made an analysis of the current student-teachers that it was identified generally to lack of basic teaching skills, flexible classroom organizational ability and effective educational resources, always keeping traditional teaching methods and holding teacher-centered teaching pattern because of mainly being not qualified and systematic. Thus, I located my training objectives of this area to expect that the student-teachers could: 1) apply a relative referenced instructional framework or templet to other different lessons; 2) state specific teaching objectives and strategies explicitly; 3) arrange appropriate 
and reasonable teaching process or steps; 4) analyze beginning learners' abilities and levels; and 5) review other lesson plans in peers or groups (Ali \& Mina, 2014).

Designing good lesson plans was a primary teaching ability or technique for teachers in teaching and learning practice, in which the teachers provided a significant structure to represent their experiences effectively (Naegle, 2002; Neeraja, 2003). While an effective lesson plan commonly had three basic components: aims and objectives of the training, teaching and learning activities, and assessments to check students' understanding of the topic (Naegle, 2002). Then, I preferred to the Demonstration Method which could help the student-teachers in having deeper understanding of the topic, and it could account for the principles of reflective thinking and impart maximum learning to them (Iline, 2013).

In view of aforementioned consideration and implementation, my overall and objective feeling of evaluation about the trainees' submission of lesson plan was that majority of the trainees basically understood how to place the framework of a lesson plan clearly, how to set the key and difficulty points properly, and how to transfer the requirements into practical classroom content appropriately by applying instructional syllabus and textbooks (Singh, 2008). Specifically, their instructional descriptions and instructions were relatively simple but clear, their teaching objectives were set basically reasonable and coincident with their teaching targets, especially, majority of the trainees added a certain procedure of Teaching Reflective Notes which was highlighted in the discussion section of Self-reflected Awareness, in which they could make a beginning to end self-checking to compare both proposed steps and performed achievements together. Therefore, it implied that they fulfilled more or less about the requirements of the teaching pattern or standard based on the present educational situation and context.

\section{Conclusions and Recommendations}

For Future Practice:

-Know overall background of learners. The training module was developed in order to improve the learners' ELT proficiency. Therefore, this training module could be used, innovated or modified by other instructors who would like to improve the learners' ELT proficiency in any levels. Instructors might design and develop more appropriate training activities in specific training phase to gain different effectiveness of different situations. As a result, the learners' basic majors, their academic levels, their learning interests, motivations and common targets, their prior knowledge of advantages and weakness, even their academic, social or emotional difficulties, and so on, should be understood thoroughly so that more impressive teaching materials, proper teaching methods, logical teaching procedures, appropriate grouping challenges and efficient classroom management, etc. could be well-designed pertinently especially in the needs analysis and training design phases.

-Establish pleasant learning environment. Creating a positive learning environment could allow the learners to feel comfortable, safe and engaged, optimize their learning, and also help build a cohesive classroom community (Hue \& $\mathrm{Li}, 2008$ ). Therefore, make full of using available teaching and learning resources and facilities firstly, such as multi-media classrooms with qualified equipments of a highdefinition projector and modern acoustics (for audio-visual activities), a spacious and context-depended classroom with changeable desks and seats (for interaction, teamwork and game-playing activities), an accessible high-speed network (for demonstrating or sharing net resources), and other relevant hardware. In addition, based on the findings of the study, such software of improvements should also be considered in terms of treating the learners respectfully, setting the rule enforcement equitably, exemplifying their behavioral and academic expectations clearly, addressing their needs intentionally, providing them constructive feedback and guidance frequently, motivating their confidence and encouraging their progress instantly, providing with opportunities to share their voices and experiences 
unconstrainedly, acknowledging the teacher's inescapable errors and the learners' negative emotions appropriately, making optimum use of the teaching and learning materials interactively, and being punctual and keeping smile for class from day one in the training development and implementation phases.

-Ensure sufficient teaching periods. Based on the recommendations from the student-teachers, it was concerned frequently on the insufficiency of teaching duration, which was also critically required as the primary aspect to be revised carefully. Just as mentioned in course syllabus, the partial training topics might be adjusted according to the practical situations without regard for some special delay. The student-teachers frequently underlined the necessity of extending or increasing the training duration in matter of the following prioritized topics: English pronunciation, comprehensive spoken English and listening ability, lesson design, teaching techniques, and presentation and evaluation of lesson. In brief, such possible influencing factors should be taken into consideration, and appropriate alternative scheme should be set to ensure sufficient and adjustable teaching periods regarding to the different training modules in order to serve the trainees' required competencies improvement, and ultimately to gain more evaluation effectiveness and satisfaction.

-Identify instructor's traits and competences. With regard to the instructor's personal accomplishments under the increasingly diverse and personalized professional learning, the learners frequently would feel satisfied with the following challenges:

1) Maintaining lasting passion, patience and creativity by performing lifelong learning with devoted responsibility and professional maturity, by paying careful attention to the possible challenges, and by holding creative expertise when presenting lesson, coaching the learners, supervising management and evaluating performance;

2) Making both verbal and written communications effective by explaining the terms accessibly and meaningfully, by using professional yet friendly body languages and by listening actively;

3) Making learning audio-visible by sharing more multimodal valuable artifacts, including texts, pictures, hand-made cards, worksheets, videos, music and songs without any reservations; and

4) Making thinking critical by creating comfortable and positive learning environments, by providing supportive services, and by setting clear behavioral and academic expectations, and so on. In sum, the instructors should be more optimistic conscientiously in career engagement than the conventional classroom teaching (Simonsen, et al., 2008; Mcllveen \& Perera, 2015).

-Consider relevant factors synthetically. In this connection, it was recommended that: more feasible studies should be done to identify the learners' imperative needs in practical ELT situations; possible commitment for developing the training program was required between both trainer and trainees in terms of budget support and time guarantee; suitable and systematic compilation of textbooks was expected for the current learners; evidence-based management practice incorporating classroom and training program should be enhanced (Simonsen, et al., 2008); equivalent criteria of recruitment for the learners' current levels of English proficiency, and certain amount of trainees (better no more than 45) even strict attendance regulation together should also be modified, restricted and be taken into account so as to gain more pertinence and effectiveness in further training practice.

For Future Research:

- Attempt alternative training models. The prioritized ADDIEM training module of the study could be adapted to seek a more complete and creative training process framework for future researches. It was also recommended to shift the training module to other majors or subjects, such as English education; and finally partially help either directly or indirectly generalize the training module to other multi-ethnic communities under the similar context of Yunnan Province. Thus, future researches may 
extend the challenge of other training models according to different emphasis in different situations, for instance, one alternative is the Dick and Carey Model, which underlines to provide detailed step-by-step processes especially for novice instructional designers to follow the systematic approach in designing instruction (Dick \& Carey, 2005); another alternative is the Kirkpatrick Model, which highlights for analyzing and evaluating the results of training to determine aptitude based on four levels criteria (Reaction, Learning, Behavior, and Results) for both informal and formal styles of training (Khalil \& Elkhider, 2016).

-Change pre-service into in-service trainees. The student-teachers studying in the current campus of the setting were concerned in the present training program as the major trainees, but they were not the same particular participants who were invited to conduct the questionnaires and interviews of the study based on their different academic grade situations of learning developments in the practical training process. Accordingly, such English teachers who are working in kindergartens and primary schools (or higher secondary levels) are proposed to be the certain participants as well as trainees from day one for future researches. Based on this, investigating the relationship between such certain English teachers' expectations and their prior knowledge, and developing other relative topics such as comprehensive competences of grammar and vocabulary, reading and writing abilities, which were not covered in the present study, also deserve to be focused as imperative and influential factors in acquiring specific ELT proficiency (Hoz, Bowman \& Kozminsky, 2001; Thompson \& Zamboanga, 2003).

\section{Limitations}

Here are three aspects of limitations:

First, the present study focused on the ELT proficiency among the student-teachers from Dali University in terms of professional development, other aspects such as personal and social competencies, which might be equally important, would not be included in the present study. Therefore, the inclusion of other traits of teacher quality could supply additional information about the ELT proficiency in Yunnan province. That should be other topics for further study.

Second, all participants in this study were selected from Dali Bai ethnic prefecture. Therefore, the results might not be generalized to other ethnic groups in other communities.

Third, all participants from pre-school and primary education majors who were studying in the current campus from 2014, 2015 academic grades were asked to respond to a questionnaire while 2016 academic grades were involved into the practical training. It meant that 2014 grade student-teachers who had finished teaching practicum might have different interpretations and definitions regarding the interval values and rankings provided by the scale compared with 2015 and 2016 grades studentteachers. To decrease varying interpretations by the participants, the scaling was made as clearer as possible.

\section{Ethics Committee Approval}

Ethical approval was obtained from Burapha University, Thailand (approval date: 10/03/2020). 


\section{References}

Ahmed, G. S. (2011). Foreign language teacher training in the Sudan: past, present and strategies for future recruitment policies. International Journal of English Linguistics, 1(2), 115-125.

Ali, J. N., \& Mina, H. (2014).The important role of lesson plan on educational achievement of Iranian EFL teachers' attitudes. International Journal of Foreign Language Teaching \& Research, 3(5), 25-31.

Amundson, S. J. (2005). Prewriting and handwriting skills. In J. Case-Smith (Ed.), Occupational therapy for children ( $5^{\text {th }}$ ed., pp. 587-614). St Louis, MO:Elsevier/Mosby.

Brown, A. H., \& Green, T. D. (2016). The essential of instructional design: Connecting fundamental principles with process and practice $\left(3^{\text {rd }}\right.$ ed.). New York: Routledge.

Clare, R. K., \& Natalie, B. M. (2014). Teaching models: Designing instruction for $21^{\text {st }}$ century learners. New York: Pearson Education, Inc.

Copeland, S. \& Oliphant, E. (2014). BSW students personal reflection and self-correction: Teaching implications. International Journal of Business, Humanities and Technology, 4(3), 45-53.

Creswell, J. W. (2009). Research design: qualitative, quantitative, and mixed methods approaches. (3 $3^{\text {rd }}$ ed.). Thousand Oaks, CA: Sage.

Creswell, J. W. (2012). Educational research: planning, conducting, and evaluating quantitative and qualitative research. ( $4^{\text {th }}$ ed.). Pearson Education, Inc.

Creswell, J. W., \& Clark, P. V. L. (2011). Designing and conducting mixed methods research ( $\left.2^{\text {nd }} e d.\right)$. Thousand Oaks, CA: Sage.

Dick, W., Carey, L., \& Carey, J. O. (editors) (2005). The systematic design of instruction ( $6^{\text {th }}$ ed.). Boston, MA: Pearson.

Eby, J. W., Herrell, A. L., \& Hicks, J. (2002). Reflective planning, teaching, and evaluation. Upper Saddle River, NJ: Merrill Prentice Hall.

Elder, W., Rakel, D., Heitkemper, M., Hustedde, C., Harazduk, N., Gerik, S., \& Haramati, A. (2007). Using complementary and alternative medicine curricular elements to foster medical student selfawareness. Academic Medicine, 82(9), 51-55.

Erdfelder, E., Faul, F., \& Buchner, A. (1996). GPOWER: A general power analysis program. Behavior Research Methods, Instruments \& Computers, 28, 1-11. doi: 10.3758/BF03203630.

Farooqui, S. (2007). Developing speaking skills of adult learners in private universities in Bangladesh: problems and solutions. Australian Journal of Adult Learning, 47 (1), 94-110.

Feder, K. P., \& Majnemer, A. (2007). Handwriting development, competency, and intervention. Developmental Medicine and Child Neurology, 49, 312-317. doi:10.1111/j.1469-8749.2007.00312.x

Fraser, H. (2000). Coordinating improvements in pronunciation teaching for adult learners of English as a second language. Canberra: DETYA.

Gagne, R. M., Wager, R. W., Golas, K. C., \& Keller, J. M. (2005). Principles of instructional design ( $5^{\text {th }}$ ed.). Belmont, CA: Thomson Wadsworth.

Gimson, A. C. (1962). An introduction to the pronunciation of English. London: Arnold. Forth edition (1989) revised by Ramsaran, S.; sixth edition (2001) revised by Cruttenden, A. Cited in Wang, Y. J. 
(2009). An effective approach to children's English phonetics teaching. Bilingual Theory and Exploration, 6, 23.

Ginnis, P. (2002). The teacher's toolkit. Carmarthen: Crown House. Cited in Graf, M. \& Birch, A. (2009). The teaching assistant's guide to understanding and support learning. London: Cataloguingin-Publication Data.

Goleman, D. (1996). Emotional Intelligence. Why it can matter more than IQ. London: Bloomsbury. Cited in Graf, M. \& Birch, A. (2009). The teaching assistant's guide to understanding and support learning. London: Cataloguing-in-Publication Data.

Graf, M., \& Birch, A. (2009). The teaching assistant's guide to understanding and support learning. London: Cataloguing-in-Publication Data.

$\mathrm{Gu}, \mathrm{L}$. (2016). The investigation of the bilingual pre-school teachers' English proficiency level and their training strategy. Journal of Jining Normal University, 3(5), 115-118.

Gustafson, K. L., \& Branch, R. M. (2002). What is instructional design. In Reiser, R.A. \& Dempsey, J.V. (Eds.). Trends and issues in instructional design and Technology. (17-25) Columbus, OH: Merrill/Prentice Hall.

Hadavandkhani, F., Bahrami, H., Behnia, F., Farahbod, M., \& Salehi, M. (2008). Handwriting difficulties: Introducing an instrument. Iranian Rehabilitation Journal, 6, 39-46.

Harmer, J. (2000). How to teach English. Beijing: Foreign Language Teaching and Research Press.

Hassan, S. \& Miraclea, R. (2009). Learning to identify educational materials. International Conference RANLP 2009. Borovets, Bulgaria, 123-127.

Hope Speak. (2014). The importance of correct pronunciation. Online published: December 16, 2014. Retrieved from https://www.hopespeak.com/blog/the-importance-of-correct-pronunciation/.

Hosni, S. A. (2014). Speaking difficulties encountered by young EFL learners. International Journal on Studies in English Language and Literature (IJSELL), 2(6), 22-30. Retrieved on April 28, 2019, from https://www.researchgate.net/publication/270340628_Speaking_Difficulties_Encountered_by_You ng_EFL_Learners.

Hoz, R., Bowman, D., \& Kozminsky, E. (2001). The differential effects of prior knowledge on learning: A study of two consecutive courses in earth sciences. Instructional Science, 29, 187-211.

Hue, M. T., \& Li, W. S. (2008). Classroom management: creating a positive learning environment. Hong Kong: Hong Kong University Press.

Huitt, W. (2011). Bloom et al.'s taxonomy of the cognitive domain. Educational Psychology Interactive. Valdosta, GA:Valdosta State University. Retrieved on March 19, 2019, from http://www.edpsycinteractive.org/topics/cognition/bloom.html.

Iline, C. S. (2013). Impacts of the demonstration method in the teaching and learning of hearing impaired children. IOSR Journal Of Humanities And Social Science (IOSR-JHSS), 12(1), 48-54.

Janes, M. D. (2018). An investigation of handwriting legibility and pencil use tasks in healthy older adults. Master's thesis, Faculty of Health Sciences, University of Sydney, June 2018.

Janice, J. B. (2017). Skills for preschool teacher $\left(10^{\text {th }}\right.$ ed.). Pearson Education, Inc.

Johnson, R. B., \& Chhetri, N. (2002). Exclusionary policies and practices in Chinese 
minority education: The case of Tibetan education. Current Issues in Comparative Education, 2 (2), 142-153.

Jordi, R. (2011). Reframing the concept of reflection: Consciousness, experiential learning, and reflective learning practices. Adult Education Quarterly, 61(2):181-197.

Kaddour, K. I. (2016). Enhancing EFL learners' speaking skill through effective communicative activities and strategies: The case of first year EFL students. Master's thesis, University of Tlemcen.

Khalil, M. K., \& Elkhider, I. A. (2016). Applying learning theories and instructional design models for effective instruction. Adv Physiol Educ, 40, 147-156. Doi:10.1152/advan.00138.2015.

Lamarca, C. A. J. (2016). Explicit pronunciation instruction to improve Thai vocational college students' intelligibility. HRD Journal, 7(1), 6-17.

Li, J. F. (2006). Research on endangered languages in southwest of China. Beijing: Central University for Nationalities Press.

Li, W. Y. (2014). Primary school English curriculum and teaching. Beijing: Chinese People University Press.

Liu, H. (2011). Strengthening training of pre-service ability and promoting in-service sustainable development -- a brief discussion on teacher training of preschool bilingual education. Vocational Technology, 5, 42-43.

Li, Y., Liu, S. Y., \& Ghil'ad, Z. (2014). The impact of language policy on the development of bilingual education for minorities in China, Higher Education of Social Science, 7(1), 51-56.

Mann, K., Gordon, J. \& MacLeod, A. (2009). Reflection and reflective practice in health professions education: a systematic review. Adv Health Sci Educ Theory Pract,14(4), 595-621.

Martin, F. (2011). Instructional design and the importance of instructional alignment.

Community College Journal of Research and Practice, 35, 955-972.

McGrath, I. (2002). Materials evaluation and design for language teaching. Edinburgh: Edinburgh University Press.

Mcllveen, P., \& Perera, H. N. (2015). Career optimism mediates the effect of personality on teachers' career engagement. Journal of Career Assessment. doi: 10.1177/1069072715616059.

Moore, M. G., \& Kearsley, G. (1996). Distance education: A systems view. New York: Wadsworth Publishing Company.

Morley, J. (1991). The pronunciation component in teaching English to speakers of other languages. TESOL Quarterly, 25(3), 481-520.

Morse, J. M., \& Niehaus, L. (2009). Mixed method design: Principles and procedures. Walnut Creek, CA: Left Coast Press.

Naegle, P. (2002). The new teacher's complete source book. USA: scholastic professional books.

Nation, I. S. P., \& Macalister, J. (2010). Language Curriculum Design. New York \& London: Routledge.

Neeraja, K. (2003). Text book of nursing education. New Delhi: Jaypee brothers medical publishers.

Phil, B. (2007). The importance of spoken English skills training in the business setting. Retrieved on September 20, 2018, from https://www.cssd.ac.uk/sites/default/files/module_5.

Pintrich, P. R., \& Schunk, D. H. (2002). Motivation in Education. Englewood Cliffs, NJ: Prentice Hall. 
Postiglione, G. A. (1999). China's national minority education: Culture, schooling and development. New York: Falmer Press. Cited in Johnson, B. and Chhetri, N. (2002). Exclusionary policies and practices in Chinese Minority Education: The case of Tibetan education. Current Issues in Comparative Education, 2(2),142-153.

Rahman, A., \& Deviyanti, R. (2012). The correlation between students' motivation and their English speaking ability. Jurnal Ilmiah ESAI, 6(1), 1-18.

Reiser, R. A., \& Dempsey, J. V. Eds. (2007). Trends and issues in instructional design and technology. Saddle River, NJ, Pearson Education.

Richards, A. S., \& Elwood, F. H. (2009). Foundations of human resource development ( $2^{\text {nd }}$ ed.). BerrettKoehler Publishers, Inc.

Richards, J. C., \& Lockhart, C. (1994). Reflective teaching in second language

classrooms, New York, Cambridge University Press. Retrieved from

https://doi.org/10.1017/CBO9780511667169.

Rosin, J. (2015). The necessity of counselor individuation for fostering reflective practice. Journal of Counseling and Development, 93(1), 88-95.

Rubin, H. J., \& Rubin, I. S. (1995). Qualitative interviewing: The art of hearing data.

Thousand Oaks, CA: Sage.

Santangelo, T., \& Graham, S. (2016). A comprehensive meta-analysis of handwriting instruction. Educational Psychology Review, 28(2), 225-265. https://doi.org/10.1007/s10648-015-9335-1.

Serdyukov, P., \& Ryan, M. (2008). Writing effective lesson plans: The 5-star approach. Boston: Allyn $\&$ Bacon.

Shen, X. M., \& Zhao, F. (2010). The professional standards and development of preschool bilingual education teachers. Studies in Preschool Education, 5, 39-43.

Silverman, E. (2008). Ongoing self-reflection. American Journal of Speech-Language Pathology, 17(1), 92.

Simonsen, B., Fairbanks, S., Briesch, A., Myers, D., \& Sugai, G. (2008). Evidence-based practices in classroom management: considerations for research to practice. Education and Treatment of Children, 31(3), 351-380.

Singh,Y. K. (2008). Teaching practice: lesson planning. New Delhi: APH publishing corporation.

Spinelli, C. G. (2011). Linking assessment to instructional strategies: A guide for teachers. Pearson Education, Inc.

Tan, D. R. (2006). Preschool bilingual education_-A case study in Chinese context. Unpublished Ph.D thesis, Fujian Normal University.

Tan, X. (2014). Existing problems and countermeasures of preschool bilingual education teachers. Journal of Suzhou Education Institute, 7(5), 79-80.

Teddlie, C., \& Tashakkori, A. (2009). Foundation of mixed methods research: Integrating quantitative and qualitative approaches in the social and behavioral sciences. Thousand Oaks, CA: Sage.

Thanasoulas, D. (2002). Motivation and motivating in the foreign language classroom. The Internet TESL Journal, 8(11), retrieved from October 2016, http://iteslj.org/Articles/ThanasoulasMotivation.html. 
Tian, F. (2007). A brief analysis of factors affecting English pronunciation learning. Journal of Jining Teachers' College, 28(3), 31-32.

Tomlinson, B. (2003). Developing materials for language teaching. London: Continuum Press.

Tsang, M. C., Yang, C. L., \& Qiu, L. (2005). Ethnic minorities education in Yunnan:

Developments, challenges and policies. Retrieved on September 12, 2017 from http://www.tc.edu/centers/coce/pdf_files/a11.pdf.

Tseng, M. H. (1998). Development of pencil grip position in preschool children.

Occupational Therapy Journal of Research, 18, 207-224.

doi:10.1177/153944929801800406.

Ur, P. (1996). A course in language teaching. Cambridge: Cambridge University Press. Retrieved on May 2, 2019, from http://www.banarvan.com/DynamicContent/UsersDirectory/admin/MyFiles/Teaching\%20Syllabus /penny\%20ur\%20old\%20version.pdf.

Wang, L. (2014). A new model of preschool bilingual teacher training in English teaching. Journal of Weifang Engineering Vocational College, 27(2), 8-10.

Wang, Y. (2007). Imperatives of strengthening the study of preschool bilingual education in China. Children Education, 2, 52 - 55.

Wang, S. P., \& Mi, H. M. (2014). A strategic study of the demand for bilingual teachers for pre-school education. Journal of Hebei Normal University(Educational Science Edition), 16(2),105-109.

Wang T. Y. (2016). How to develop children's English teaching activities effectively. New Curriculum, 1,63 .

Wang, Y. J. (2009). An effective approach to children's English phonetics teaching. Bilingual Theory and Exploration, 6, 23.

Yao, D., \& Li, Z. H. (2010). Research and exploration on pre-service training mode of preschool bilingual education. Journal of HuBei Adult Education Institute, 16(2), 8-10.

Yavuz, F., \& Celik, G.Y. (2017). Using fairy tales as a model to enhance learners' writing organization skill. International Journal of Learning and Teaching, 9(3), 349-353.

Zeng, M. (2008). The role of grammatical instruction within communicative language teaching among Chinese ESL students. CELEA Journal, 31(1), 36-45.

Zhu, F. Y. (2007). The current situation of preschool English education and its requirements for teachers. Journal of Inner Mongolia Normal University (Education and Science Edition), 12, 67-69.

Zimmerman, B. J. (2002). Becoming a self-regulated learner: An overview. Theory Into Practice, 41(2), $65-70$. 


\section{Çok etnik gruptan oluşan toplum okullarındaki öğrenci öğretmenler arasında ilk ELT yeterliliğini artırmak için bir eğitim modülünün geliştirilmesi}

\section{$\ddot{O} \mathbf{z}$}

$\mathrm{Bu}$ çalışma, öğrenci-öğretmenlerin mesleki gelişiminin mevcut ihtiyaçlarını araştırmayı, ELT yeterliliklerini geliştirmek ve etkinliğini belirlemek için bir eğitim modülü geliştirmeyi amaçlamıştır. Çeşitli araştırma verilerinin ortaya çıkarılmasında, nicel ve daha sonra nitel araştırma yöntemlerinden başlayarak, paralel strateji ile karma yöntem araştırma tasarımı kullanılmıştır. 168 katılımcı (öğrenci-öğretmen ve İngilizce öğretmeni), 18 katılımcı (ebeveyn, anaokulu İngilizce öğretmeni, yöneticiler ve paydaşlar) ve 58 katılımcı (öğrenci-öğretmen) ile farklı aşamalarda çok sayıda araç kullanılmıştır. ADDIEM eğitim süreci, eğitim modülünü geliştirme çerçevesi için bir kılavuz olarak benimsenmiştir. Çalışma şu çıktılarla sonuçlanmıştır: 1) dört dönüştürülmüş eğitim modülü (Dilsel Temeller, Ders Tasarımı, Öğretim Teknikleri ve Öğretim Gösterisi) içinde on dört öncelikli konu mevcut öğrenciöğretmenlerin karşılaştı̆̆ zorluklar olarak belirlenmiş̧tir; 2) eğitim hedefleri ve müfredatı, ders planları, öğretim stratejileri, eğitim katılımcıları ve yeri, eğitimin verilmesi, eğitimin değerlendirilmesi ve geliştirilmesi her aşamada eğitim faaliyetlerinin özel bileşenleri olarak sıralanmıştır; 3) ihtiyaç analizi, tasarım, geliştirme, uygulama, değerlendirme ve modifikasyonun altı aşamasından oluşan ADDIEM Eğitim Süreci, uygulanabilir bir eğitim modülü geliştirmek için sistematik olarak birleştirildi ve eğitim programı, büyük fayda ve memnuniyet sağladığı için kabul edildi. Son olarak, iyi bir öğretme ve öğrenme ortamı oluşturma, yeterli eğitim süreleri sağlama, eğiticinin mesleki özelliklerini ve yeterliliklerini belirleme, kursiyerlerin arka plan bilgilerini belirleme, hizmet modellerini hizmet düzeyinde değiş̧irmeye yönelik gelecek için yapıcı öneriler yapıldı.

Anahtar Sözcükler: Eğitim modülü; Profesyönel geliştirme; ADDIEM eğitim süreci; ELT yeterliliği; çok etnik gruptan oluşan gruplar

\section{AUTHOR BIODATA}

Youxing Xiao, Ph. D. Associate Pro. Majoring in Preschool education. Faculty of Teacher and Education, Dali University, China.

Janpanit Surasin, Ph. D. Assistant Pro. Majoring in Language/ cross-cultural teacher/ trainer; Wanderer and social observer.

Denchai Prabjandee, Ed.D. Teaching English as a Global Language Faculty of Education, Burapha University, Thailand. 